\section{Individual psychophysical functions for 28 odorants*}

\author{
B. BERGLUND $\dot{\dagger}, \mathrm{U}$. BERGLUND, and G. EKMAN \\ University of Stockholm, Stockholm, Sweden \\ and \\ T. ENGEN \\ Brown University, Providence, Rhode Island 02912
}

Individual scales of odor intensity were obtained for 28 different chemical compounds by the method of magnitude estimation. Eleven Ss participated in an experiment with 196 olfactory stimuli which differed in both quality and intensity. It was found (1) that power functions described the relationship between partial vapor pressure of the odorants and their subjective odor intensity for all Ss, (2) that all exponents were less than one but varied greatly between Ss, (3) that consistent intraindividual differences in the exponents of different odorants exist, and (4) that these are attributable to perceptual differences rather than to response bias.

Early psychophysical studies of olfaction were concerned primarily with the problem of odor quality, but, with the advent of direct psychophysical methods, more attention has recently been paid to the relationship between stimulus intensity and the corresponding subjective intensity. It has thus been shown that the perceived intensity is a negatively accelerated function of physical intensity. The relationship is practically always described by a power function $R=c S n$, where the value of $n$ is less than one. The exponents obtained in different studies have been found to range between 0.13 for octanol and 0.72 for eugenol.

In an early study of odor intensity with the use of a magnitude-estimation method, an exponent of 0.2 was obtained for benzaldehyde in air by Reese and Stevens (see Stevens, 1957, p. 166). Jones (1958a,b) studied systematically nine different organic compounds, which were presented to Ss in test tubes containing the odorants in liquid form, and he found that the exponents of the power function ranged from 0.42 for $n$-butanol to 0.58 for pyridine. Exponents of approximately the same magnitude were also obtained by Reese and Stevens (1960) for the odors of heptane and coffee diluted in air. In a

\footnotetext{
*This research was carried out while Trygg Engen (Walter $S$, Hunter Laboratory of Psychology, Brown University, Providence, Rhode Island 02912) was visiting the Perception and Psychophysics Unit of the Psychological Laboratories, University of Stockholm. The study was supported by grants from the Bank of Sweden Tercentenary Fund and the Swedish Council for Social Science Research. The authors are indebted to Dr,W.S. Dockens III ior assistance in the experimental work and to Mr. J. Ernfridsson and Dr.E. Högfeldt for assistance with the chemical analysis.

tAddress: Psychological Laboratories, University of Stockholm, Box 6801, S-11386 Stockholm, Sweden.
}

number of experiments with liquid odorants by Engen and his associates, the exponent of the power function was found to range from a value as low as 0.13 for octanol to 0.57 for amyl acetate (Engen, 1961, 1965; Engen \& Lindström, 1963; Engen, Cain, \& Rovee, 1968; Cain \& Engen, 1970; see also Cain, 1969). Engen (1961) has pointed out that occasional deviations observed from the power function may be due to changes in perceived quality that sometimes accompany changes in the intensity of an odorant.

Results of 10 investigations are summarized in Table 1. The table is based on the scaling of perceived odor intensity of different chemical compounds and serves as a review of direct scaling experiments in this area. It is difficult to make comparisons among the different studies since, unfortunately, chemical formulas, as well as information about the purity of the odorants, are usually insufficient or lacking. Another complication is the type of dilutent (air, gas, or liquid) used. An interesting finding made by Cain (1969) was that air-diluted compounds tend to give higher exponents than do the same compounds presented in liquid form, although relative values of the exponents are independent of the method of dilution and presentation of the stimulus. Furthermore, comparisons of the exponents are difficult to make, because sometimes partial vapor pressure and sometimes concentration in volume percent is used as the physical measure of intensity. Obviously, the same values of the parameter of the power function cannot be expected for two physical scales that are not linearly related. However, as the molecular weight of the odorant approaches the molecular weight of the dilutent, the relative values of the scales approach a linear relationship. This is the reason that the exponent for octanol is almost the same in both units, but the exponent for propanol is not.

The subject of the present investigation is the individual differences in the exponent of the power function. A brief review of this problem is presented by Ekman, Hosman, Lindman, Ljungberg, and Akesson (1968) for several psychophysical continua. An early study of individual functions was performed by Künnapas (1958), who studied apparent length of lines and verified the power function for all his Ss. J.C. Stevens and Mack (1959) noted that, despite individual differences in the slopes of psychophysical functions, the power function described the individual as well as the group scales of apparent force obtained by both magnitude estimation and magnitude production (see also S.S. Stevens, 1960). Similar results were obtained for sensory continua such as loudness of 1,000-Hz tone (J. C. Stevens \& Guirao, 1964), brightness of white light (Marks \& J. C. Stevens, 1966), and saltiness of sodium chloride and sweetness of sucrose (Ekman \& Akesson, 1965). Among the scaling experiments concerned with olfactory intensity, one by Jones and Marcus (1961) has reported individual data. A median exponent of 0.56 $\left(Q_{1}=0.47\right.$ and $\left.Q_{3}=0.93\right)$ was found for the odor of benzene.

In the present case, individual scales of perceived odor intensity were obtained for a large sample of odorants with a procedure permitting direct intraindividual comparisons of these scales. A magnitude-estimation method was used, with one standard as a reference for all variables independent of the intensity and quality.

\section{Stimuli}

\section{THE EXPERIMENT}

In the present experiment 28 different chemical compounds, the purest available commercially, were used as odorants. They were chosen with regard to both chemical and psychological characteristics according to five criteria: (1) None of the chemical compounds should exceed the rating 2 ("moderate") in Sax's (1966) system of toxic hazards regarding inhalation. (2) A large variation in molecular weight and vapor pressure (at $20^{\circ} \mathrm{C}$ ) was desired, as well as a variation in chemical structure of the chemical compounds. (3) Different characteristics of solubility in polar and nonpolar substances were to be represented. (4) The different compounds should produce qualitatively different odors. (5) Both pleasant and unpleasant odors should be included in the stimulus sample.

Each of the 28 odorants was diluted into seven steps in a geometric series according 
to the formula $\left(100 / 2^{n}\right) \%$, where $n$ ranged from 0 to 6 , such that the concentrations ranged from $100 \%$ to $1.56 \%$ in equal $\log$ steps. The percentages represent milliliters of odorant per $4 \mathrm{ml}$ of the solution. For three of the compounds, guaiacol, menthol, and phenyl acetic acid, which are crystals in pure form, the $100 \%$ solution was replaced by $50 \%, 40 \%$, and $28 \%$, respectively, the highest liquid concentrations available for these particular odorants. Diethyl phthalate was used as dilutent, except for $n$-heptane, nonane, and n-octane, which were diluted in silicon oil. It was assumed that all solutions would deviate negligibly from ideal behavior when diluted in diethy! phthalate. Therefore, the partial vapor pressures of the odorous compounds in $\mathrm{mm} \mathrm{Hg}$ at $20^{\circ} \mathrm{C}$ were calculated from the molefraction according to Raoult's law. With regard to n-heptane, direct vapor pressure measurements were performed on the solution of $n$-heptane in silicon oil. Since the same vapor pressure was found for $n$-heptane in silicon oil as in vacuum, it can be concluded that the silicon oil has a negligible vapor pressure. On the assumption that Raoult's law is applicable, the molecular weight of silicon oil was calculated from the data obtained from the solution of $n$-heptane in silicon oil. This value was then used in the calculations of the vapor pressure for nonane and n-octane diluted in silicon oil according to Raoult's law. All chemical compounds used in the experiment are presented in Table 2.

The experiment w.us performed in a well-ventilated room of $30 \mathrm{~m}^{3}$, with a fan evacuating $1.5 \mathrm{~m}^{3}$ of air per minute. The stimuli were presented by a technique used earlier by Engen (1965). The prepared solutions were kept at a temperature of ca $20^{\circ} \mathrm{C}$ in $15 \times 100 \mathrm{~mm}$ glass tubes with a cork wrapped in aluminum foil. Attached to each cork was a glass rod with a piece of cotton wrapped around its lower end. The Ss sniffed the odors from the cotton, which was contained in the tube and partially immersed in the liquid odorant when not in use.

\section{Procedure}

The method of magnitude estimation with a modulus was used. A standard acetone at $100 \%$ concentration (vapor pressure of $175 \mathrm{~mm} \mathrm{Hg}$ at $20^{\circ} \mathrm{C}$ ) was presented before a block of seven variable stimuli. The Ss were asked to call this standard 100 , to memorize its perceived intensity, and then to estimate the perceived intensity of subsequent stimulus variables in relation to it. The same standard was used throughout the
Table 1

Summary of Results Concerning Power Functions for Different Odorants

\begin{tabular}{|c|c|c|c|c|c|}
\hline Odorant & Dilutent & $\begin{array}{l}\text { Scaling } \\
\text { Method }\end{array}$ & $\begin{array}{c}\text { Number } \\
\text { of Ss }\end{array}$ & $\begin{array}{c}\text { Expo- } \\
\text { nent }\end{array}$ & Reference \\
\hline Acetone & Air & $\begin{array}{l}\text { Magnitude } \\
\text { estimation }\end{array}$ & 15 & .71 & Cain (1969) \\
\hline Amyl acetate & $\begin{array}{l}\text { Benzyl } \\
\text { benzoate }\end{array}$ & $\begin{array}{l}\text { Magnitude } \\
\text { estimation }\end{array}$ & 4 & .33 & Engen (1961) \\
\hline Amyl acetate & $\begin{array}{l}\text { Benzyl } \\
\text { benzoate }\end{array}$ & $\begin{array}{l}\text { Magnitude } \\
\text { estimation }\end{array}$ & 4 & .20 & Engen (1961) \\
\hline Amyl acetate & $\begin{array}{l}\text { Benzyl } \\
\text { benzoate }\end{array}$ & $\begin{array}{l}\text { Magnitude } \\
\text { estimation }\end{array}$ & 13 & $.49^{\mathrm{c}}$ & Engen \& Lindstrom (1963) \\
\hline Amyl acetate & $\begin{array}{l}\text { Benzyl } \\
\text { benzoate }\end{array}$ & $\begin{array}{l}\text { Ratio } \\
\text { estimation }\end{array}$ & 13 & .42 & Engen \& Lindstrom (1963) \\
\hline Amyl alcohol & Air & $\begin{array}{l}\text { Magnitude } \\
\text { estimation }\end{array}$ & 15 & .56 & Cain (1969) \\
\hline Benzaldehyde & Air & $\begin{array}{l}\text { Magnitude } \\
\text { estimation }\end{array}$ & 30 & .20 & $\begin{array}{l}\text { Stevens }(1957) \text { and } \\
\text { personal communication }\end{array}$ \\
\hline Benzene & $\begin{array}{l}\text { Mineral } \\
\text { oil }\end{array}$ & $\begin{array}{l}\text { Magnitude } \\
\text { estimation }\end{array}$ & 36 & .55 & Jones (1958b) \\
\hline Benzene & -- & $\begin{array}{l}\text { Magnitude } \\
\text { estimation }\end{array}$ & 52 & $.56^{\mathrm{b}}$ & Jones \& Marcus (1961) \\
\hline n-Butanola & $\begin{array}{l}\text { Mineral } \\
\text { oil }\end{array}$ & $\begin{array}{l}\text { Magnitude } \\
\text { estimation }\end{array}$ & 36 & .42 & Jones (1958a) \\
\hline n-Butanol & $\begin{array}{l}\text { Diethyl } \\
\text { phtalate }\end{array}$ & $\begin{array}{l}\text { Magnitude } \\
\text { estimation }\end{array}$ & 12 & .23 & Cain (1969) \\
\hline n-Butanol & Air & $\begin{array}{l}\text { Magnitude } \\
\text { estimation }\end{array}$ & 15 & .64 & Cain (1969) \\
\hline $\sec -B_{u} \operatorname{tanol}{ }^{a}$ & $\begin{array}{l}\text { Mineral } \\
\text { oil }\end{array}$ & $\begin{array}{l}\text { Magnitude } \\
\text { estimation }\end{array}$ & 36 & .57 & Jones (1958a) \\
\hline iso-Butanol ${ }^{a}$ & $\begin{array}{l}\text { Mineral } \\
\text { oil }\end{array}$ & $\begin{array}{l}\text { Magnitude } \\
\text { estimation }\end{array}$ & 36 & .56 & Jones (1958a) \\
\hline Coffee & Air & $\begin{array}{l}\text { Magnitude } \\
\text { estimation }\end{array}$ & 12 & .55 & Reese \& Stevens (1960) \\
\hline Cyclohexane $^{a}$ & $\begin{array}{l}\text { Mineral } \\
\text { oil }\end{array}$ & $\begin{array}{l}\text { Magnitude } \\
\text { estimation }\end{array}$ & 36 & .44 & Jones (1958a) \\
\hline $\begin{array}{l}\text { Dimethyl } \\
\text { disulphide }\end{array}$ & Air & $\begin{array}{l}\text { Finger span } \\
\text { matching }\end{array}$ & 8 & .40 & $\begin{array}{l}\text { Berglund, Berglund, \& } \\
\text { Lindvall (In preparation) }\end{array}$ \\
\hline $\begin{array}{l}\text { Dimethyl } \\
\text { monosulphide }\end{array}$ & Air & $\begin{array}{l}\text { Finger span } \\
\text { matching }\end{array}$ & 8 & .41 & $\begin{array}{l}\text { Berglund, Berglund, \& } \\
\text { Lindvall (In preparation) }\end{array}$ \\
\hline Ethyl acetate $\mathrm{a}^{\mathrm{a}}$ & $\begin{array}{l}\text { Mineral } \\
\text { oil }\end{array}$ & $\begin{array}{l}\text { Magnitude } \\
\text { estimation }\end{array}$ & 36 & .53 & Jones (1958a) \\
\hline Eugenol & Air & $\begin{array}{l}\text { Magnitude } \\
\text { estimation }\end{array}$ & 20 & .72 & Mitchell \& Gregson (1968) \\
\hline Geraniol & $\begin{array}{l}\text { Diethyl } \\
\text { phtalate }\end{array}$ & $\begin{array}{l}\text { Magnitude } \\
\text { estimation }\end{array}$ & 12 & .20 & Cain (1969) \\
\hline Geraniol & $\mathrm{Air}$ & $\begin{array}{l}\text { Magnitude } \\
\text { estimation }\end{array}$ & 15 & .29 & Cain (1969) \\
\hline Heptane $^{a}$ & $\begin{array}{l}\text { Mineral } \\
\text { oil }\end{array}$ & $\begin{array}{l}\text { Magnitude } \\
\text { estimation }\end{array}$ & 52 & .55 & Jones (1958b) \\
\hline Heptane & Air & $\begin{array}{l}\text { Magnitude } \\
\text { estimation }\end{array}$ & 18 & .60 & Reese \& Stevens (1960) \\
\hline Heptanol & $\begin{array}{l}\text { Diethyl } \\
\text { phtalate }\end{array}$ & $\begin{array}{l}\text { Magnitude } \\
\text { estimation }\end{array}$ & 12 & .15 & Cain (1969) \\
\hline Hexanol & $\begin{array}{l}\text { Diethyl } \\
\text { phtalate }\end{array}$ & $\begin{array}{l}\text { Magnitude } \\
\text { estimation }\end{array}$ & 12 & .16 & Cain (1969) \\
\hline Octane $\mathrm{e}^{\mathrm{a}}$ & $\begin{array}{l}\text { Mineral } \\
\text { oil }\end{array}$ & $\begin{array}{l}\text { Magnitude } \\
\text { estimation }\end{array}$ & 52 & .55 & Jones (1958a) \\
\hline Octanol & $\begin{array}{l}\text { Diethyl } \\
\text { phtalate }\end{array}$ & $\begin{array}{l}\text { Magnitude } \\
\text { estimation }\end{array}$ & 11 & .15 & Cain (1969) \\
\hline Octanol & $\begin{array}{l}\text { Diethyl } \\
\text { phtalate }\end{array}$ & $\begin{array}{l}\text { Magnitude } \\
\text { estimation }\end{array}$ & 11 & .13 & Engen (1965) \\
\hline Propanol & $\begin{array}{l}\text { Diethyl } \\
\text { phtalate }\end{array}$ & $\begin{array}{l}\text { Magnitude } \\
\text { estimation }\end{array}$ & 11 & .42 & Engen (1965) \\
\hline
\end{tabular}


Table 1 (Continued)

\begin{tabular}{cllccc}
\hline Odorant & Dilutent & $\begin{array}{c}\text { Scaling } \\
\text { Method }\end{array}$ & $\begin{array}{c}\text { Number } \\
\text { of Ss }\end{array}$ & $\begin{array}{c}\text { Expo- } \\
\text { nent }\end{array}$ & Reference \\
\hline Propanol & $\begin{array}{l}\text { Diethyl } \\
\text { phtalate }\end{array}$ & $\begin{array}{l}\text { Magnitude } \\
\text { estimation }\end{array}$ & 12 & .38 & Cain (1969) \\
Propanol & $\begin{array}{l}\text { Diethyl } \\
\text { phtalate } \\
\text { Propanol }\end{array}$ & $\begin{array}{l}\text { Magnitude } \\
\text { estimation } \\
\text { phtalate }\end{array}$ & 12 & .36 & Cain (1969) \\
Propanol & $\begin{array}{l}\text { Magnitude } \\
\text { estimation }\end{array}$ & 12 & .52 & Cain (1969) \\
Pyridine & $\begin{array}{l}\text { Magnitude } \\
\text { estimation }\end{array}$ & 15 & .69 & Cain (1969) \\
\hline
\end{tabular}

Vapor pressure is used as physical scale of intensity. $b_{\text {Median }}$ of 52 individually obtained exponents. $c_{M e a n}$ of obtained exponents for different standards.

experiment. It was chosen to represent the upper end of the subjective intensity continuum for the whole set of 28 odorants in order to obtain estimates in submultiples, since some Ss have been found not to handle both multiples and fractions properly at the same time (Svenson \& Akesson, 1966; see also Stevens, 1956). Only part of the total set of 196 stimuli was presented in any one session in order to minimize adaptation and cross-adaptation effects due to extensive exposure to a $100 \%$ acetone standard.

The comparison odorants, varying in both quality and intensity, were presented in a different irregular order for each $\mathrm{S}$, in which each individual stimulus appeared four times. The stimulus order was drawn at random but modified such that for each compound the lowest, the third lowest, the fifth lowest, and the highest concentration was placed next to the standard at least once in the whole random set. This restriction was made in order to balance out a possible change in the memory or state of adaptation due to the standard that might be present within the blocks.

Each of the 196 different stimuli was presented four times to each $\mathrm{S}$ in sessions comprising 70-77 comparison stimuli. Eleven such sessions, usually two each day, were run per $S$. A session lasted about $20 \mathrm{~min}$, with intervals of $15 \mathrm{sec}$ between stimuli and a rest of $20 \mathrm{~min}$ between sessions.

\section{Subjects}

Eleven Ss, five men and six women, participated in the experiment. All but $\mathrm{E}$, $G, H$, and $K$ were psychology students, but none of them had any previous experience in olfactory experiments.

\section{RESULTS}

The individual exponents of $t_{1} e$ odorants represent the main results of this study and are presented in Table 3. Individual scales of odor intensity for each of the 28 odorants were computed by averaging the four estimates for each stimulus. A straight line representing a power function seems to fit the data fairly well in all 308 individual graphs, when these arithmetic means are plotted in $\log -\log$ coordinates against the stimulus concentration measured as partial vapor pressure. ${ }^{2}$ Of course, it may be possible to fit other types of mathematical functions to some of the data plots because of scatter of points, but there seem to be no systematic trends over individuals or odorants indicating that a different function would be better.

A comparison of the individual scales suggests that there is a positive correlation over Ss in the range of numbers assigned to the different odorants. This effect is even more evident in the results for all $\mathrm{Ss}$ and odorants. Whether this apparent correlation may be related to interindividual differences in olfactory sensitivity or ability in handling numbers cannot be decided on the basis of present data.

As indicated, some of the Ss apparently did not perceive any differences in intensity for some of the odorants, but with three exceptions this phenomenon is limited to certain odorants for certain Ss. That is, the results of all Ss for diethy] monosulphide, n-heptanal, and phenyl acetic acid vary little in perceived intensity within the stimulus range investigated. The stimulus range for these three odorants probably covers only an extremely small part of the possible dynamic range. It would be useful to determine whether the absolute thresholds for these odorants are low compared to the lowest intensity used in the present experiment.

Table 3 also shows that the size of the individual exponents of two of the Ss, D and I, deviate remarkably from those of the other Ss. With a few exceptions, the exponents for $D$ and $I$ are less than 0.10 , and, in addition, their numerical estimates are generally high in magnitude relative to the standard. The very narrow numerical range used by these two high estimators could be related to uncertainty and problems of discrimination, but, interestingly, there does not seem to be any obvious difference between them and the rest of the Ss as far as the ability to rank-order stimulus intensities is concerned.

In order to evaluate the interindividual differences in the relative size of exponents over the different odorants, a product-moment correlation was calculated on the rank orders of exponents for paired Ss because of presence of ties. In computing these coefficients, the empty cells of Table 3 were regarded as containing zero exponents. Despite the great number of tied ranks, these coefficients range from 0.12 to 0.65 . Even S D (0.14-0.65) and S I (0.23-0.65), with their narrow response ranges, correlated as well with each other and the rest as did any of the other Ss.

In addition, Kendall's W was calculated for the whole group, and the value of 0.44 obtained corresponds to an average rank coefficient of 0.38 and is significant at the $0.1 \%$ level, according to a chi-square test (cf. Ferguson, 1959, p. 188). There is no indication that valuable information about the exponents for different odorants will get distorted or lost when the results are summarized in terms of group data.

The exponents of the average scales of perceived intensity obtained by computing the arithmetic means of the 11 individual scales for each of the 28 odorants are presented in the last column of Table 3. Straight lines fitted to these functions by eye seem to fit very well in all except two cases (diethyl monosulphide and n-heptane). 2 This indicates that the power function governs the relationship between perceived intensity and partial vapor pressure for different odorants. The arithmetic means of the individual exponents are also presented in Table 3 The exponents obtained through these two different procedures show a rank-order coefficient of correlation of 0.70 . There is no evidence of any systematic difference between group functions and individual functions, even though the latter are based on only four estimates per stimulus. Finally, it should be noted that the exponents obtained for all the 28 odorants are less than one for all individuals.

\section{Individual Functions}

\section{DISCUSSION}

The finding that the psychophysical power function yields a satisfactory fit to nearly all individual data for the 28 different odorants is noteworthy, since published data on the psychophysical function for the individual $S$ s is limited, especially in the area of olfaction. This kind of information is particularly 
Table 2

Chemical Compunds Used as Stimuli in the Experiment

\begin{tabular}{|c|c|c|c|c|c|c|c|}
\hline Chemical compound & Purity* & $\begin{array}{l}\text { Molecular } \\
\text { weight }\end{array}$ & $\begin{array}{l}\text { Density at } \\
20^{\circ} \mathrm{C}\end{array}$ & $\begin{array}{l}\text { Vapor pressure } \\
\text { in } \mathrm{mm} \mathrm{Hg}_{\mathrm{g}} \text { at } \\
200 \mathrm{C}\end{array}$ & $\begin{array}{l}\text { Solubility in } \\
\text { g/100 ml } \mathrm{H}_{2} \mathrm{O} \\
\text { at ca. } 20^{\circ} \mathrm{C}\end{array}$ & Odor & $\begin{array}{l}\text { Stimulug range } \\
\left(5_{\max } / \mathrm{S}_{\text {min) in }}\right. \\
\text { vapor presoure }\end{array}$ \\
\hline $\begin{array}{l}\text { Acctone } \\
\mathrm{CH}_{3} . \mathrm{CO} \cdot \mathrm{CH}_{3}\end{array}$ & pro analysi & 58. $0 \mathrm{~B}$ & 0.792 & 175 & $=$ & $\begin{array}{l}\text { Mildly pungent. } \\
\text { momewhat a romatic }\end{array}$ & 24. 33 \\
\hline $\begin{array}{l}\text { n-Amyl acetate } \\
\mathrm{CH}_{3} \cdot \mathrm{COO}\left(\mathrm{CH}_{2}\right)_{4} \cdot \mathrm{CH}_{3}\end{array}$ & . & 130.19 & 0.879 & 3.27 & 0.18 & Apples, Janana: & 48. 09 \\
\hline $\begin{array}{l}\text { Anethole } \\
\mathrm{CH}_{3}, \mathrm{CH}: \mathrm{CH} . \mathrm{C}_{6} \mathrm{H}_{4}, \mathrm{O}^{\mathrm{CH}_{3}}\end{array}$ & purum & 148.21 & 0.985 & 0.03 & 0 & Ane thole & 49. 18 \\
\hline $\begin{array}{l}\text { Benaldehyda } \\
\mathrm{C}_{6} \mathrm{H}_{5} . \mathrm{CHO}\end{array}$ & puries. & 106.12 & 1.050 & 0.2 & 0.33 & Bitter atmond: & 33.14 \\
\hline $\begin{array}{l}\text { Bunxy1 acerste } \\
\mathrm{CH}_{3}, \mathrm{COOCH}_{2}, \mathrm{C}_{6} \mathrm{H}_{5}\end{array}$ & purum & 150.18 & 1.057 & 0.07 & 0 & Jatmine, pears & 46. 0.5 \\
\hline $\begin{array}{l}\text { I- Butanol } \\
\mathrm{CH}_{3} \cdot\left(\mathrm{CH}_{2}\right)_{2}, \mathrm{CH}_{2} \mathrm{OH}\end{array}$ & pro analyai & 74. 12 & 0.810 & 4.3 & 7.91 & Weak fusel oil & 30.11 \\
\hline $\begin{array}{l}\text { n- Butyric acid } \\
\mathrm{CH}_{3} \cdot \mathrm{CH}_{2} \cdot \mathrm{CH}_{2} \cdot \mathrm{COOH}\end{array}$ & puries. & 88.11 & 0.959 & 0.7 & $=$ & Pungent. rancid & 30.38 \\
\hline $\begin{array}{l}\text { Diethyl monosulphide } \\
\mathrm{CH}_{3} \cdot \mathrm{CH}_{2} \cdot \mathrm{S} \cdot \mathrm{CH}_{2} \cdot \mathrm{CH}_{3}\end{array}$ & purum & 90.18 & 0.837 & 48 & 0.313 & Unplea sant & 35.29 \\
\hline $\begin{array}{l}\text { Diethyl phtalate } \\
\mathrm{C}_{6} \mathrm{H}_{4}\left(\mathrm{COOC}_{2} \mathrm{H}_{5}\right)_{2}\end{array}$ & puries. & 222.24 & 1.123 & 0 & 0.7 & None & - \\
\hline $\begin{array}{l}\text { Ethanol } \\
\mathrm{CH}_{3}, \mathrm{CH}_{2} \mathrm{OH}\end{array}$ & $99.5 \%$ & 46.07 & 0.790 & 41 & $\infty$ & Etherual odor & 19. 84 \\
\hline $\begin{array}{l}\text { Ethyl acctate } \\
\mathrm{ClI}_{3} \cdot \operatorname{coOC}_{2} \mathrm{H}_{5}\end{array}$ & pro analyai & 88. 11 & 0.901 & 71 & 8.6 & Fruity & 31.86 \\
\hline $\begin{array}{l}\text { Ethyl methyl ketone } \\
\mathrm{C}_{2} \mathrm{H}_{5}, \mathrm{CO} \mathrm{CH}_{3}\end{array}$ & pro analye: & 72.11 & 0.805 & 21.2 & 35.3 & Acctonclike & 29.48 \\
\hline $\begin{array}{l}\text { Eugenol } \\
\mathrm{CH}_{2}: \mathrm{CH}_{0} \mathrm{CH}_{2}, \mathrm{C}_{6} \mathrm{H}_{3}\left(\mathrm{O} . \mathrm{CH}_{3}\right) \cdot \mathrm{OH}\end{array}$ & purum & 164.21 & 1.066 & 7.1 & 0 & Clove & 50.02 \\
\hline $\begin{array}{l}\text { Furfurole } \\
\text { O.CH:CH. CH: C. } \mathrm{CHO}\end{array}$ & pro analyal & 96.09 & 1. 159 & 1.1 & 8. 3 & Almond odor & 27.36 \\
\hline $\begin{array}{l}\text { Geranial } \\
\left(\mathrm{CH}_{3}\right)_{2} \mathrm{C}: \mathrm{CH}_{2} \mathrm{CH}_{2} \cdot \mathrm{CH}_{2} \cdot \mathrm{C}\left(\mathrm{CH}_{3}\right): \mathrm{CH} . \mathrm{CHO}\end{array}$ & purum & 152.24 & 0.847 & 0.03 & ) & Lemon. sweet rose & 55.56 \\
\hline $\begin{array}{l}\text { Gua iacol } \\
\mathrm{CH}_{3} \cdot \mathrm{O}^{\circ} \cdot \mathrm{C}_{6} \mathrm{H}_{4} \cdot \mathrm{OH}\end{array}$ & puriss. & 124. 14 & 1. 129 & 0.06 & 1. 16 & Agreable aromatic & 45.92 \\
\hline $\begin{array}{l}\mathrm{n}-\mathrm{Heptanal} \\
\mathrm{CH}_{3} \cdot\left(\mathrm{CH}_{2}\right)_{5} \cdot \mathrm{CHO}\end{array}$ & pro analysi & 114.19 & 0.850 & 1.9 & 0 & Penetrating fruity & 43. 76 \\
\hline $\begin{array}{l}\text { n-Heptane } \\
\mathrm{CH}_{3} \cdot\left(\mathrm{CH}_{2}\right)_{5} \cdot \mathrm{CH}_{3}\end{array}$ & pro analyzi & 100.21 & 0.684 & 34 & 0.0052 & Ganoline & 19. 30 \\
\hline $\begin{array}{l}\text { 1- Heptanol } \\
\mathrm{CH}_{3} \cdot\left(\mathrm{CH}_{2}\right)_{5} \cdot \mathrm{CH}_{2} \mathrm{OH}\end{array}$ & puriss. & 116.21 & 0.822 & 0.15 & 0.09 & 一 & 46.01 \\
\hline $\begin{array}{l}\text { Menthol } \\
\mathrm{CH}_{3}\end{array}$. $\mathrm{CH} \cdot \mathrm{CH}_{2} \cdot \mathrm{CH}(\mathrm{OH}), \mathrm{CH}\left[\mathrm{CH}\left(\mathrm{CH}_{3}\right)_{2}\right] \cdot \mathrm{CH}_{2} \cdot \mathrm{CH}_{2}$ & puriss. & 156.27 & 0.890 & 0.003 & 0.04 & Prppermint & 60.94 \\
\hline $\begin{array}{l}\text { Methyl ealicylate } \\
\text { HO } \mathrm{C}_{6} \mathrm{H}_{4} \mathrm{COOCH}_{3}\end{array}$ & purum & 152.15 & 1.194 & 0.009 & 0.074 & Strong winter reen & 41.86 \\
\hline $\begin{array}{l}\text { Nonane } \\
\mathrm{CH}_{3} \cdot \mathrm{CH}_{2} \cdot \mathrm{CH}_{2} \cdot \mathrm{CH}_{2} \cdot \mathrm{CH}_{2} \cdot \mathrm{CH}_{2} \cdot \mathrm{CH}_{2} \cdot \mathrm{CH}_{2} \cdot \mathrm{CH}_{3}\end{array}$ & pract. & 128.25 & 0.716 & 7.22 & 0 & Candied ginger & 47.1 \\
\hline $\begin{array}{l}\text { n-Octane } \\
\mathrm{CH}_{3} \cdot\left(\mathrm{CH}_{2}\right)_{6} \cdot \mathrm{CH}_{3}\end{array}$ & pract. & 114.22 & 0.707 & 10 & 0.0015 & - & 17.4 \\
\hline $\begin{array}{l}\text { 1. Octanol } \\
\mathrm{CH}_{3} \cdot\left(\mathrm{CH}_{2}\right)_{6}\end{array} \mathrm{CH}_{2} \mathrm{OH}$ & puriss. & 130.23 & 0.825 & 0.01 & - & Penetrating aromatic & 51.26 \\
\hline 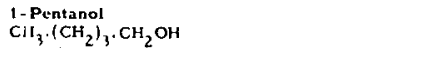 & pro anulysi & 88.15 & 0.817 & 2.8 & 0 & Characteristic odor & 35.32 \\
\hline $\begin{array}{l}\text { Phenyl acetic anid } \\
\mathrm{C}_{6} \mathrm{H}_{5} \cdot \mathrm{CH}_{2} \cdot \mathrm{COOH}\end{array}$ & puriss. & 136. 15 & 1. 228 & 0.0001 & 1.66 & - & 52.63 \\
\hline $\begin{array}{l}\text { 2. Phenyl ethyl alcohol } \\
\mathrm{C}_{6} \mathrm{H}_{5} \cdot \mathrm{CH}_{2} \cdot \mathrm{CH}_{2} \mathrm{OH}\end{array}$ & purum & 122.17 & 1.024 & 0.002 & 1.6 & Faint rose & 38.99 \\
\hline $\begin{array}{l}\text { Pyridine } \\
\mathrm{N}: \mathrm{CH} . \mathrm{CH}: \mathrm{CH} . \mathrm{CH}: \mathrm{CH}\end{array}$ & pro analysi & 79.10 & 0.982 & 14 & $x$ & Ditagreeable & 26.64 \\
\hline $\begin{array}{l}\text { Silicon oil } \\
\text { DC } 702\end{array}$ & & 337.00 & 1.070 & 0 & - & None & - \\
\hline $\begin{array}{l}\text { : } 10 \text {-Valeric acid } \\
\left(\mathrm{CH}_{3}\right)_{2} \cdot \mathrm{CH}_{2} \mathrm{CH}_{2} \cdot \mathrm{COOH}\end{array}$ & puriss. & 102.14 & 0.931 & 0.4 & 4.2 & $\begin{array}{l}\text { Disagrceable. } \\
\text { rancid checee }\end{array}$ & 39.89 \\
\hline
\end{tabular}

* Pro analysi is the highest purity grade for analytical work. Puriss. is of min $99 \%$ purity; purum is of min $98 \%$ purity, and pract. is of high but varying purity. All purity grades of the chemicals are guaranteed against containing any additional odor except the characteristic one. From The Handbook of Chemistry \& Physics, 1969.

invaluable in comparing psychophysical functions in general. For example, the finding that intraindividual differences in the exponent for qualitatively different odorants are less than interindividual differences in the exponent for any particular odor might suggest the operation of nonsensory factors (Jones \& Marcus, 1961).
Since characteristic exponents of the power functions are found to relate psychophysical magnitude to stimulus magnitude, the exponent may be described as "modality bound" (S. S. Stevens, 1961). Of course, individual differences in the exponent have been found for different continua as well as for qualitative variation within one sense modality (Ekman \&
Sjöberg, 1965; Ekman, Hosman, \& Lindström, 1965; Ekman \& Åkesson, 1965; S. S. Stevens, 1968; Cain, 1969). Two possible interpretations of the interindividual variation in the exponent of the psychophysical function have been proposed; it may reflect genuine perceptual differences or some kind of response bias related to the S's conception of numerical 
Table 3

Individual and Mean Exponents of the Power Functions for the 28 Odorants. Cells with a bar indicate that the $S$ could not discriminate odor intensity within the range investigated for that particular odorant.

\begin{tabular}{|c|c|c|c|c|c|c|c|c|c|c|c|c|c|c|c|}
\hline \multirow[b]{2}{*}{ Odorant } & \multicolumn{11}{|c|}{ Subject } & \multirow[b]{2}{*}{ Mean } & \multirow[b]{2}{*}{ SD } & \multirow[b]{2}{*}{ Range } & \multirow{2}{*}{$\begin{array}{r}\text { Group } \\
\text { Expo- } \\
\text { nent }\end{array}$} \\
\hline & A & $\mathrm{B}$ & $\mathrm{C}$ & $\mathrm{D}$ & $\mathbf{E}$ & $\mathrm{F}$ & $G$ & $\mathbf{H}$ & I & $\mathrm{J}$ & $\mathrm{K}$ & & & & \\
\hline Acetone & 0.94 & 0.63 & 0.59 & 0.12 & 0.79 & 0.40 & 0.49 & 1.02 & 0.14 & 0.73 & 0.13 & 0.54 & 0.32 & $0.12-1.02$ & .34 \\
\hline n-Amyl acetate & 0.10 & 0.18 & 0.24 & 0.07 & 0.08 & 0.04 & 0.23 & 0.11 & 0.05 & 0.26 & 0.06 & 0.13 & 0.08 & $0.04-0.26$ & .11 \\
\hline Anethole & 0.17 & 0.21 & 0.14 & 0.07 & 0.21 & 0.14 & 0.09 & 0.22 & 0.04 & 0.32 & 0.14 & 0.16 & 0.08 & $0.04-0.32$ & .15 \\
\hline Benzaldehyde & 0.27 & 0.30 & 0.17 & 0.13 & 0.38 & 0.09 & 0.24 & 0.24 & 0.07 & 0.11 & 0.09 & 0.19 & 0.10 & $0.07-0.38$ & .16 \\
\hline Benzyl acetate & -- & 0.10 & 0.23 & 0.05 & 0.35 & 0.22 & 0.25 & 0.36 & 0.07 & 0.32 & 0.17 & 0.21 & 0.11 & $0.05-0.36$ & .15 \\
\hline l-Butanol & 0.37 & 0.70 & 0.27 & 0.04 & 0.72 & 0.16 & 0.33 & 0.30 & 0.03 & 0.32 & 0.20 & 0.31 & 0.23 & $0.03-0.72$ & .22 \\
\hline n-Butyric acid & 0.41 & 0.39 & 0.07 & 0.04 & 0.33 & 0.12 & 0.18 & 0.41 & 0.07 & 0.26 & 0.11 & 0.22 & 0.15 & $0.04-0.41$ & .16 \\
\hline Dimethyl monosulphide & -- & -- & 0.16 & -- & 0.07 & 0.05 & -- & 0.03 & -- & -- & -- & $(0.08)$ & $(0.06)$ & $(0.03-0.16)$ & $-\rightarrow$ \\
\hline Ethanol & -- & 0.40 & 0.23 & 0.11 & 1.00 & 0.19 & $\ldots$ & 0.27 & 0.09 & -- & 0.12 & 0.30 & 0.30 & $0.09-1.00$ & .07 \\
\hline Ethyl acetate & 0.43 & 0.33 & 0.07 & 0.08 & 0.29 & 0.17 & 0.19 & 0.25 & 0.10 & 0.27 & 0.10 & 0.21 & 0.12 & $0.07-0.43$ & .19 \\
\hline Ethyl methyl ketone & 0.65 & 0.42 & 0.47 & 0.10 & 0.37 & 0.25 & 0.24 & 0.48 & 0.08 & 0.45 & 0.15 & 0.33 & 0.18 & $0.08-0.65$ & .27 \\
\hline Eugenol & 0.29 & 0.34 & 0.19 & 0.08 & 0.69 & 0.22 & 0.21 & 0.21 & 0.09 & 0.45 & 0.15 & 0.27 & 0.18 & $0.08-0.69$ & .19 \\
\hline Furfurole & 0.15 & 0.70 & 0.24 & 0.04 & 0.29 & 0.13 & 0.25 & 0.49 & 0.07 & 0.47 & 0.25 & 0.28 & 0.20 & $0.04-0.70$ & .23 \\
\hline Geranial & 0.23 & 0.39 & 0.16 & 0.08 & 0.15 & 0.05 & 0.21 & 0.12 & 0.04 & 0.39 & 0.10 & 0.17 & 0.12 & $0.04-0.39$ & .13 \\
\hline Guaiacol & 0.32 & 0.40 & 0.30 & 0.09 & 0.37 & 0.24 & 0.08 & 0.23 & 0.04 & 0.24 & 0.20 & 0.23 & 0.12 & $0.04-0.40$ & .17 \\
\hline n-Heptanal & -- & -- & -- & -- & 0.05 & $-\cdot$ & -- & 0.18 & -- & 0.06 & -- & $(0.10)$ & $(0.07)$ & $(0.05-0.18)$ & -- \\
\hline n-Heptane & 0.48 & 0.55 & -- & 0.10 & -- & 0.14 & 0.11 & 0.43 & 0.08 & 0.77 & 0.08 & 0.30 & 0.26 & $0.08-0.77$ & .19 \\
\hline Heptanol & 0.12 & 0.24 & 0.20 & 0.04 & 0.28 & 0.10 & $-\cdots$ & 0.19 & -- & 0.31 & 0.04 & 0.71 & 0.10 & $0.04-0.31$ & .09 \\
\hline Menthol & 0.36 & 0.64 & 0.13 & -- & -- & 0.21 & 0.15 & 0.31 & 0.04 & 0.20 & $\cdots$ & 0.26 & 0.19 & $0.04-0.64$ & .11 \\
\hline Methyl salicylate & 0.28 & 0.31 & 0.18 & 0.04 & 0.26 & 0.25 & -- & 0.15 & 0.04 & 0.28 & 0.16 & 0.20 & 0.10 & $0.04-0.31$ & .12 \\
\hline Nonane & 0.27 & 0.73 & 0.08 & 0.04 & 0.44 & 0.13 & 0.22 & 0.38 & $\cdots-$ & 0.48 & 0.24 & 0.30 & 0.21 & $0.04-0.73$ & .13 \\
\hline n-Octane & 0.16 & 0.57 & 0.30 & 0.06 & 0.16 & 0.11 & -- & 0.28 & 0.08 & 0.61 & 0.10 & 0.24 & 0.20 & $0.06-0.61$ & .15 \\
\hline lOctanol & 0.31 & 0.38 & 0.03 & 0.06 & 0.17 & -- & -- & 0.11 & 0.02 & 0.09 & 0.07 & 0.14 & 0.13 & $0.02-0.38$ & .09 \\
\hline 1-Pentanol & -- & 0.23 & 0.15 & 0.07 & 0.50 & 0.07 & 0.26 & 0.28 & 0.05 & 0.26 & 0.14 & 0.20 & 0.14 & $0.05-0.50$ & .15 \\
\hline Penyl acetic acid & -- & -- & 0.05 & -- & 0.20 & -- & 0.07 & 0.12 & $-\cdots$ & 0.06 & -- & $(0.10)$ & (0.06) & $(0.05-0.20)$ & .08 \\
\hline 2-Phenyl ethyl alcohol & -- & 0.35 & -- & 0.03 & 0.08 & 0.08 & 0.16 & 0.36 & -- & 0.23 & 0.21 & 0.19 & 0.12 & $0.03-0.36$ & .06 \\
\hline Pyridine & 0.30 & 0.70 & 0.25 & 0.17 & 0.25 & 0.22 & 0.06 & 0.23 & 0.08 & 0.25 & 0.15 & 0.24 & 0.17 & $0.06-0.70$ & .27 \\
\hline iso-Valeric acid & 0.21 & 0.29 & 0.24 & 0.04 & 0.22 & 0.19 & 0.12 & 0.33 & 0.10 & 0.30 & 0.22 & 0.21 & 0.09 & $0.04-0.33$ & .16 \\
\hline
\end{tabular}

quantity. Jones and Marcus (1961) determined individual exponents and performed an analysis of variance for three sense modalities including odor, and they concluded that interindividual differences largely reflected differences in handling numbers. In later experiments with a large number of psychologically very different continua, Ekman et al (1968) found that correlations (ca 0.40 ) between subjective ranges were low compared to the reliability coefficients characteristic of the individual scales (ca 0.96). Although the present paper was not designed to deal directly with the issue, the data obtained are relevant. Of particular interest is the fact that the interindividual variability, with regard to the exponent in the present study (Table 3), is of the same order of magnitude as the variability found for other sensory continua (Ekman et al, 1968).

\section{The Power Function for Different Odorants}

The exponents obtained for the different compounds in the present study seem to reveal genuine perceptual differences. The experimental design permits the interpretation that the numerical response range used by the $S s$ is not limited to one particular odorait. which would be the case in a mure conventional design when each odorant is scaled in separate experiments. The scaling of an odorant is performed in the context of the whole set of odorants, and the tendency noted above for each $S$ to use the same range of numbers in separate experiments is avoided (Jones \& Marcus, 1961; Ekman et al, 1968).

It should be noted, though, that for the $S$ there was presumably only one total range of perceptual intensity for the whole set of 196 stimuli, and, therefore, the physical ranges of individual odorants scaled could not logically have affected the specific response range chosen for each odorant. As a result, it can be assumed that the variation in the exponents is characteristic of the odorants rather than of response bias. The relatively high rank-order correlations obtained for pairs of Ss and the fact that the variation in stimulus range $\left(\mathrm{S}_{\mathrm{max}} / \mathrm{S}_{\min }\right)$ in vapor pressure (Table 2) accounts for less than $25 \%$ of the total variance also support this interpretation.

For smaller samples of odorants, the relative value of the exponents have been shown to correspond to the physical property of water solubility. Cain (1969) has obtained high positive rank-order coefficients of correlation between these variables, both with regard to his owr. data and to data from Jones (1958a). That finding is not supported on the basis of the present larger sample of odorants (Table 2). The rank-order coefficient of correlation is only +0.27 and +0.25 for group exponents and averaged individual exponents, respectively.
Some of the present odorants have also been scaled in earlier studies, and the results are not always in agreement. However, it should be borne in mind that the comparison of group results from small samples of individuals is limited, owing to the relatively large individual differences in the exponent. For example, the exponents obtained earlier for amyl acetate (e.g., Cain \& Engen, 1970) are higher than our group exponents. On the other hand, exponents obtained for other odorants, for example, acetone, butanol, and octanol, agree with those obtained here, despite differences in experimental design (e.g., Cain, 1969). The task of the Ss in the present experiment must be more difficult than that in the typical scaling experiment, for they work relatively long hours and, therefore, motivational effects may be more likely to play a role (S.S. Stevens \& Greenbaum, 1966). Finally, effects of adaptation and cross-adaptation are often expected in studies of olfaction, but they probably did not affect the present results. If they had, the exponents should have been higher rather than lower than those obtained in other studies, because the effect of adaptation seems to increase the exponent in olfaction (Cain \& Engen, 1970) as in other modalities (J.C. Stevens \& S. S. Stevens, 1963).

\section{REFERENCES}

CAIN, W. S. Odor intensity: Differences in the exponent of the psychophysical function. 
Perception \& Psychophysics, 1969, 6, 349-354.

CAIN, W. S., \& ENGEN, T. Olfactory adaptation and the scaling of odor intensity. In C. Pfaffmann (Ed.), Olfaction and taste III. New York: Rockefeller University Press, 1969. Pp. 127-141.

EKMAN, G., HOSMAN, B., LINDMAN, R. LJUNGBERG, L., \& ÅKESSON, C. A. Interindividual differences in scaling performance. Perceptual \& Motor Skills, 1968, 26, 815-823.

EKMAN, G., HOSMAN, J., \& LINDSTRÖM, B Roughness, smoothness, and preference: A study of quantitative relations in individual subjects. Journal of Experimental Psychology, $1965,70,18-26$

EKMAN, G., \& SJÖBERG, L. Scaling. Annual Review of Psychology, 1965, 16, 451-474.

EKMAN, G., \& AKESSON, C. A. Saltiness, sweetness, and preference: A study of quantitative relations in individual subjects. Scandinavian Journal of Psychology, 1965, 6, 241-253.

ENGEN, T. Direct scaling of odor intensity. Report from the Psychological Laboratories, University of Stockholm, 1961, No. 106.

ENGEN, T. Psychophysical analysis of the odor intensity of homologous alcohols. Journal of Experimental Psychology, 1965, 70, 611-616.

ENGEN, T., CAIN, W. S., \& ROVEE, C. $K$. Direct scaling of olfaction in newborn infant and the adult human observer. In N. Tanyolac (Ed.), Theories of odors and odor measurement. Istanbul: Robert College, 1968. Pp. 272-294.

ENGEN, T., \& LINDSTRÖM, C. 0
Psychophysical scales of the odor intensity of a myl acetate. Scandinavian Journal of Psychology, 1963, 4, 23-28.

FERGUSON, G. A. Statistical analysis in psychology and education. New York McGraw-Hill, 1959.

JONES, F. N. Scales of subjective intensity for odors of diverse chemical nature. American Journal of Psychology, 1958a, 71, 305-310.

JONES, F. N. Subjective scales of intensity for the three odors. American Journal of Psychology, 1958b, 71, 423-425.

JONES, F. N., \& MARCUS, M. J. The subject effect in judgments of subjective magnitude. Journal of Experimental Psychology, 1961 61, 40-44.

KÜNNAPAS, T. Measurement of subjective length in the vertical-horizontal illusion. Acta Psychologica, 1958, 14, 371-374.

MARKS, L. E., \& STEVENS, J. C. Individual brightness functions. Perception \& Psychophysics, 1966, 1, 17-24.

MITCHELL, M. J., \& GREGSON, R. A. M Psychophysical power law exponent value for the olfactory intensity of eugenol. Perceptual \& Motor Skills, 1968, 26, 720 .

REESE, T. S., \& STEVENS, S. S. Subjective intensity of coffee odor. American Journal of Psychology, 1960, 73, 424-428.

SAX, N. I. Dangerous properties of industrial materials. New York: Reynold, 1966.

STEVENS, J. C., \& GUIRAO, M. Individual loudness functions. Journal of the Acoustical Society of America, 1964, 36, 2210-2213.

STEVENS, J. C., \& MACK, D. J. Scales of apparent force. Journal of Experimental Psychology, 1959, 58, 405-413.

STEVENS, J. C., \& STEVENS, S. S. Brightness function: Effects of adaptation. Journal of the Optical Society of America, 1963, 53, 375-385.

STEVENS, S. S. The direct estimation of sensory magnitudes: Loudness. American Journal of Psychology, 1956, 69, 1-25.

STEVENS, S. S. On the psychophysical law. Psychological Review, 1957, 64, 153-181.

STEVENS, S. S. The psychophysics of sensory function. American Scientist, 1960, 48, 226-253.

STEVENS, S. S. To honor Fechner and repeal his law. Science, 1961, 133, 80-86.

STEVENS, S. S. Tactile vibration: Change of exponent with frequency. Perception \& Psychophysics, 1968, 3, 223-228.

STEVENS, S. S., \& GREENBAUM, H. B. Regression effect in psychophysical judgment. Perception \& Psychophysics, 1966, 1 , 439-446.

SVENSON, 0., \& AKESSON, C. A. Fractional and multiple estimates in ratio scaling. Report from the Psychological Laboratories, University of Stockholm, 1966, No. 202.

\section{NOTES}

1. Berglund, B., Berglund, U., \& Lindvall, T. Perceived odor intensity of two organic sulfides and mixtures thereof. In preparation.

2. Graphs showing both individual and average psychophysical functions are available in a preliminary report of the data and may be obtained by writing the authors at Psychological Laboratories, University of Stockholm, Box 6801, S-113 86 Stockholm, Sweden.

(Accepted for publication August 14, 1970.) 